\title{
An inventory and risk-based prioritization of Steep Creek Fans in Alberta, Canada
}

\author{
Kris Holm ${ }^{1, a}$, Matthias Jakob ${ }^{1}$ and Elisa Scordo ${ }^{1}$ \\ ${ }^{1}$ BGC Engineering Inc., 500-980 Howe Street, Vancouver, British Columbia, Canada
}

\begin{abstract}
In June 2013, heavy rainfall caused flooding on most rivers in the province of Alberta, Canada, producing one of Canada's most expensive natural disasters with about $\$ 6$ billion (CDN) in damage. Flooding inundated several municipalities including downtown Calgary, the fourth-largest city in Canada. Debris flows and debris floods caused extensive highway closures and damages to development on alluvial fans. Following these events, the Government of Alberta requested an inventory of all fans intersecting municipal development, major roads and highways in Alberta. Such fans may be subject to debris flow, debris flood (mud flows), and/or flood hazards. The study area spans the entirety of the Alberta Rocky Mountains, approximately 51,000 km² (7\% of Alberta). We characterize 710 fans in terms of hazard level and presence and types of elements at risk. We statistically analyse watershed attributes to predict the dominant fan hydrogeomorphic process types. All fans under provincial jurisdiction are assigned priority ratings based on hazard levels and the presence and value of elements at risk. The prioritization is risk-based as it considers both hazards and potential consequences. Of the fans prioritized, $13 \%$ intersected parcels containing land and residential developments with an assessed value of $\$ 2.4$ billion (CDN), and the remainder were crossed by roads, pipelines or transmission lines. We present the study results on an interactive, searchable web application that can support ongoing hazard and risk assessments and risk reduction planning.
\end{abstract}

\section{Introduction}

In June 2013, two days of high-intensity rainfall in southwestern Alberta triggered the most expensive natural disaster in Canadian history. A low-pressure system, blocked by a high-pressure system to the north, caused 48-hour precipitation to exceed $100 \mathrm{~mm}$. Flooding occurred along all major river systems and hundreds of debris flows and debris floods were triggered on steeper tributaries (e.g. Figure 1). Province-wide, four lives were lost, 100,000 people were displaced, and transportation corridors were severed including closure of the TransCanada Highway for one week. Direct damage costs exceeded $\$ 6$ billion (CDN) and recovery is ongoing [1].

Following immediate response and recovery efforts, the Government of Alberta commissioned studies to improve the understanding and management of flood, debris flood and debris flow hazard and risk within the province. Prior to 2015, Alberta lacked a province-wide inventory of developed "steep creek" fans subject to debris flow, debris flood or flood hazards (herein referred to as hydrogeomorphic hazards) and there were no specific guidelines helping practitioners and regulators in risk management of steep creeks. Steep creeks are defined as those containing channel gradients equal to or exceeding approximately 3 degrees [2].

\footnotetext{
${ }^{\mathrm{a}}$ Corresponding author: kholm@bgcengineering.ca
}

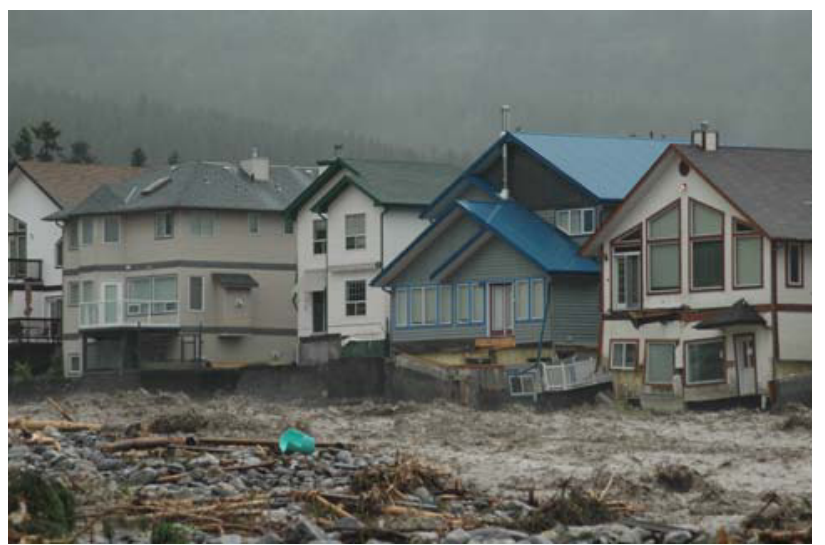

Figure 1. Cougar Creek debris flood on June 20, 2013. Photo: Town of Canmore

In this study we identified and assessed steep creek fans in Alberta that contain linear infrastructure or residential development. All of these fans are located within or on the eastern slopes of the Rocky Mountain Region, a 51,000 $\mathrm{km}^{2}$ area bordering the western edge of the province (Figure 2). The study includes areas under provincial jurisdiction as well as federally managed First Nations reserves and Banff and Jasper National Parks. The study excluded fans with minimal development (e.g., trails or minor roads) and those in the National parks containing only park facilities. The study includes fan mapping and hazard characterization, identification of development at risk, and risk-based prioritization of 
hazard areas to support risk reduction planning. Fans within the federally managed parks and First Nations reserves are characterized but not prioritized.

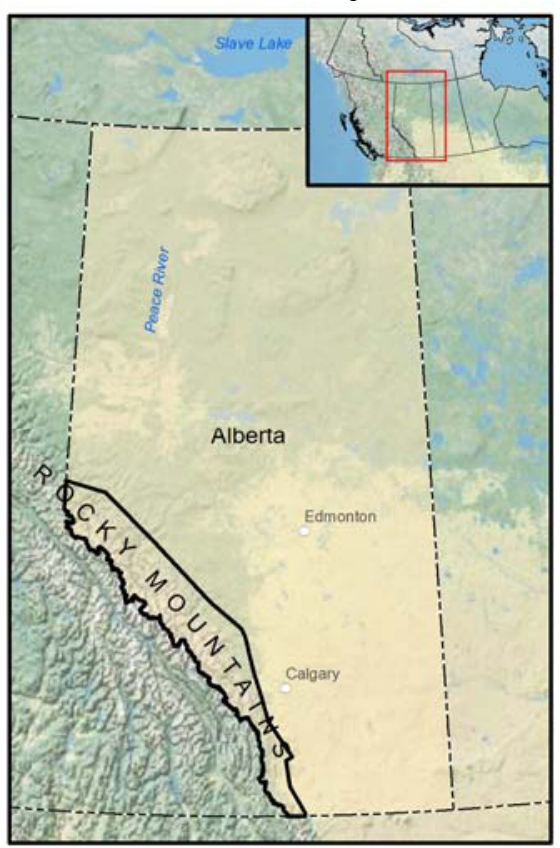

Figure 2. Study area (black outline)

\subsection{Study Area}

The study area is underlain by faulted and folded sedimentary rocks and contains four major river basins, all glaciated at their headwaters. Furthest north, the Peace/Slave and Athabasca basins drain northeastward as part of the Mackenzie continental drainage system. In the mid and southern Rockies, the North and South Saskatchewan basins drain eastward as part of the Nelson-Churchill continental drainage system. The South Saskatchewan River Basin contains the Red Deer, Bow River and Oldman River sub-basins. These sub-basins, particularly the Bow River, contain most of the developed fans within the study area.

Most of these fans originated during the transition from glaciation to deglaciation at the end of the late Pleistocene (approx. 11,700 years BP), as geomorphic processes supplied sediment to the channel system of steep creeks. These sediment yields were highest immediately following deglaciation, with an exponential decline over time. Despite the decline in sediment yields, periodic hydrogeomorphic events still occur [3-5] and threaten development.

The Rocky Mountains have a continental climate with warm summers and cold winters (Figure 3). The majority of heavy storms occur in the month of June, which is also the month with the highest precipitation amount (Figure 4). Most regional floods are caused by rainfall, secondarily by snow melt, although rain-on-snow is considered a contributing factor to flooding in June 2013 [6].

A record of damaging floods on major river systems extends back to 1897 within Alberta. However, despite the century-long history of recorded major flood events, records do not exist at regional scale for debris flow and debris flood fans. Previous assessments of Cougar Creek in the Town of Canmore identified debris flood and/or flood events reported in 1948, 1956, 1967, 1974, 1980, 1990, 1995, 2003, 2005, 2012, and June 2013 [7]. Most of those records do not include peak flows or the volume of sediment transported.

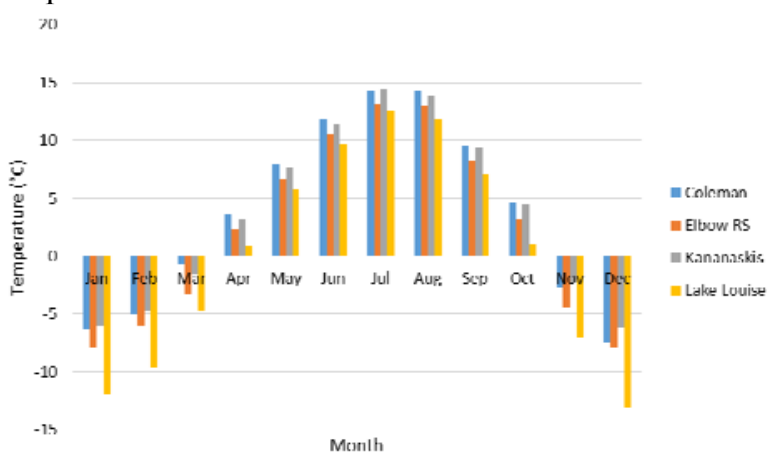

Figure 3. Temperature normals for Environment Canada's Coleman, Elbow RS, Kananaskis, and Lake Louise climate stations for the period of 1981 to 2010 [8].

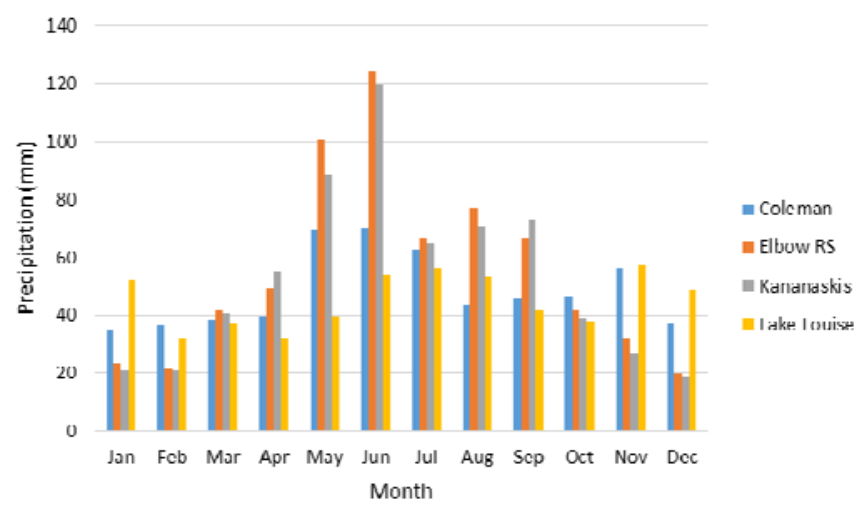

Figure 4. Precipitation normals for Environment Canada's Coleman, Elbow RS, Kananaskis, and Lake Louise climate stations for the period of 1981 to 2010 [8].

\subsection{Previous Work}

BGC Engineering Inc. (BGC) completed quantitative debris-flow and debris-flood hazard assessments for 15 steep creek fans in the Town of Canmore and Municipal District of Bighorn, located about $100 \mathrm{~km}$ west of Calgary. Risk assessments and conceptual mitigation designs were completed for 10 fans [9-30]. These assessments are the most detailed steep creek risk assessments in Alberta and were the primary data source for these fans. Previous studies also delineated fans through portions of the central study area [31-32], which we refined based on 2013 Light Detection And Ranging (LiDAR) imagery. A geohazard review was completed of fans along Highways 40 and 541 south of Canmore [33]; and emergency inspections of highway channel crossings were conducted following the June 2013 floods [34]. These inspections were used to identify channels subject to debris flow or debris flood events during the 2013 event. 


\section{Hazard Characterization}

Hazard ratings were assigned to all steep creek fans in the study area. The sections below describes methods used to classify process types (debris flow, debris flood, or flood), estimate flow statistics, and assign relative ratings for hazard frequency, avulsion and bank erosion susceptibility, and landslide dam outbreak flood potential.

\subsection{Fan Mapping}

Fan extents were interpreted based on 2013, $1.5 \mathrm{~m}$ resolution SPOT satellite imagery and hillshade images built from 2013, 1 m resolution LiDAR Digital Elevation Models (DEM) (Figure 5). LiDAR coverage is available for approximately two thirds of the study area, and hillshade images from a $25 \mathrm{~m}$ resolution GeoBase DEM ${ }^{\mathrm{a}}$ are used for the remainder. Fan boundaries and hazard ratings are less certain for areas without LiDAR coverage.

A total of 710 fans were mapped, of which 105 were field checked. The primary objectives of field assessment include surface observations to calibrate remote-sensed interpretations and identify channels with evidence for recent (e.g., June 2013) events. Subsurface investigations, channel hikes, or upper basin inspections are not completed except for those fans investigated in detail by BGC [9-30].

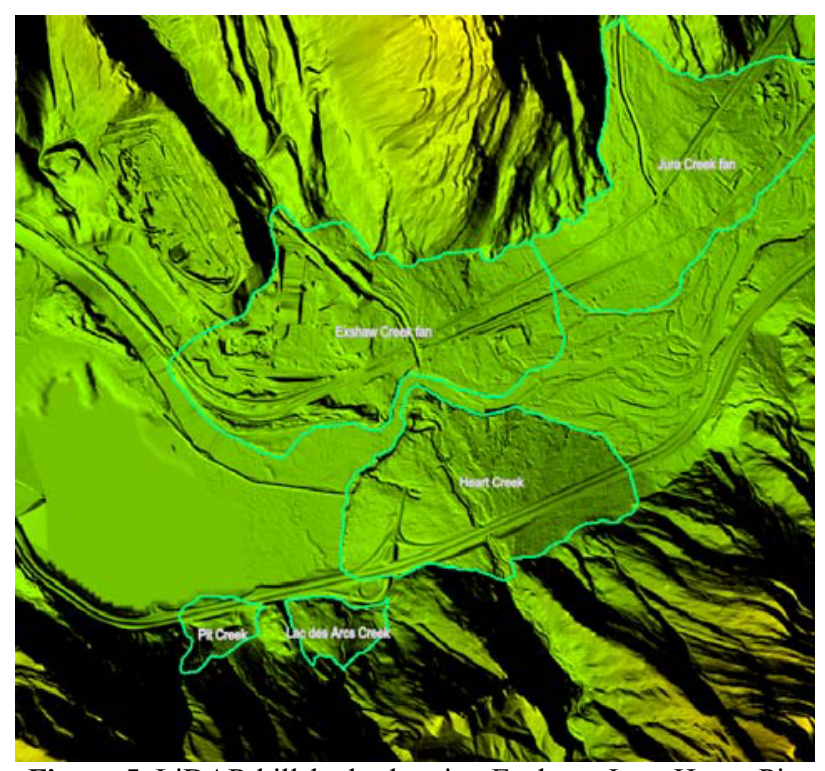

Figure 5. LiDAR hillshade showing Exshaw, Jura, Heart, Pit, and Lac des Arcs fans

\subsection{Hydrological Analyses}

Channels used for hydrological analysis were based on the Alberta Hydro Network [35] except where uppermost basins extended into British Columbia. The National Hydro Network was used for watershed areas with British Columbia, with channels manually joined to the Alberta Hydro network to ensure channel connectivity.

\footnotetext{
a Technically, GeoBase grid cell resolution is 3/4 arc-second, or about $20 \mathrm{~m}$ north-south and $23 \mathrm{~m}$ east-west in southern Canada.
}

\subsubsection{Stream Network Identification}

A "stream network" refers to the spatial integration of watercourses (streams or rivers) into a network draining from the headwaters through a catchment area to an outlet. GIS and database-driven analyses are applied to generate basin and channel characteristics for all channels within the study area. Every watercourse in the network is given a unique segment identification in ArcGIS and was overlain on a $25 \mathrm{~m}$ resolution GeoBase DEM. A combination of manual work and automated processing using ArcGIS Spatial Analyst and hydrology tools available in ArcGIS are used to generate topographic characteristics such as total catchment area upstream of each stream segment defined as channel segments between vertices on a channel polyline.

A total of 170 fans inventoried within the study area do not intersect a mapped stream. Because a defined channel is required for flood frequency analysis, flow and watershed statistics were not computed for these fans. A hydrogeomorphic process type is assigned to these fans based on terrain interpretation, fieldwork, and our review of previous work [9-34].

\subsubsection{Flood Frequency Analysis}

Various studies [36-37] show that steep creeks, defined as those with average gradients greater than 3 degrees [2], produce flows that can be up to two orders of magnitude higher than flows for comparable return periods as determined by traditional flood frequency analysis (FFA). For example, the 100-year peak instantaneous flow for Cougar Creek was previously estimated at $16 \mathrm{~m}^{3} / \mathrm{s}$ [38] using regional hydrological analysis. In comparison, the peak flow of the 2013 debris flood on Cougar Creek likely reached 100 to $120 \mathrm{~m}^{3} / \mathrm{s}$ corresponding to a return period of approximately 400 years [9]. Traditional FFA has proven to be inappropriate to estimate peak discharge, stage or flood volumes for hazard zoning or engineering applications, especially since such analyses ignore sediment transport which are key components in determining risk.

The above limitations notwithstanding, FFA does provide a starting point to compare creek flows and can be completed remotely at regional scale using available data. It also serves as one input to estimate debris flow or debris flood peak discharges. Flood quantiles for 100year flood return periods are estimated at the fan apex using regional analysis based on publicly available maximum annual peak instantaneous streamflow ( $\mathrm{Q}_{\text {IMAX }}$ ) data from Water Survey of Canada (WSC) hydrometric stations [39]. For each channel, a list of appropriate WSC gauge stations was generated by filtering for stations with multiple years of streamflow data, similar catchment area, are within an approximate $200 \mathrm{~km}^{2}$ radius of the location of interest as an initial gauge selection filter, and are not on a regulated watercourse. Peak flows were estimated for various return periods by first fitting a Generalized Extreme Value (GEV) distribution to the $\mathrm{Q}_{\text {IMAX }}$ data from the selected gauge station(s) and extrapolating the results to the location of interest using a linear regression analysis based on drainage area. 


\subsection{Hydrogeomorphic Process Assignment}

Steep creeks are subject to hydrogeomorphic processes whose dominant driver is water with varying sediment concentrations; these include clear water flood, debris flood, and debris flow process types [37]. The process type assignment does not specifically contribute to the fan prioritization rating. However, it is important for more detailed assessment of flow magnitude and behaviour, the choice of parameters for numerical modeling of flows, criteria used to estimate vulnerability and associated risk, and design of risk reduction measures.

We used two methods to assign hydrogeomorphic processes: terrain interpretations and morphometric statistics. The statistically predicted process was applied to every stream segment in the entire study area, which totals about $77,000 \mathrm{~km}$ in length. These process types were considered alongside terrain interpretations to assign a dominant process type to each fan.

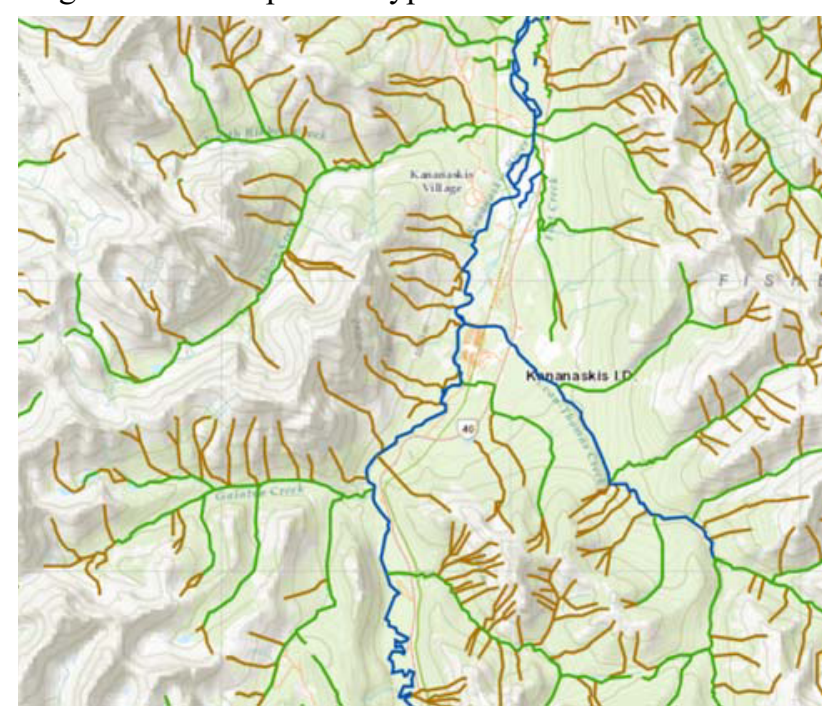

Figure 6. Statistically predicted debris flow (brown), debris flood (green) and flood (blue) stream process types near Kananaskis Village.

\subsubsection{Terrain-Interpreted Process Type}

We interpreted the dominant process types for each fan from the following information sources:

- The geomorphology of fans and their associated watersheds observed in the available imagery

- Field observations

- Records of previous events

- Review of statistically predicted process type for channel(s) intersecting the fan

While a single process type was assigned to a given fan, many fans are subject to more than one process type. Fans classified as subject to debris flows are often also subject to floods and sometimes debris floods. Those classified as debris flood fans may be subject to floods, but will generally not be subject to debris flows as those fans are typically steeper. Those classified as subject to floods were interpreted as not subject to debris floods or debris flows.

\subsubsection{Statistically Predicted Process Type}

Debris flow fans in the Canadian Rocky Mountain are typically steeper than 4 degrees and have steep, first or second Strahler order drainage basins with Melton ratios greater than 0.25 to 0.3 [40-42].

A previous study in the region combine Melton ratio with straight-line watershed length to differentiate between fans subject to debris flow, debris flood, or flood processes [43], where watershed length is considered the longest planimetric straight-line distance from the fan apex to the most distant point on the watershed boundary. Straight-line watershed length measurements were deemed appropriate for that study because the watersheds examined were long and linear, and because the measurement could be easily executed with GIS tools available at the time [44]. Table 1 summarizes the class limits described in their study.

\begin{tabular}{|c|c|c|}
\hline Process & Melton Ratio & $\begin{array}{c}\text { Watershed Length } \\
\text { (km) }\end{array}$ \\
\hline Floods & $<0.3$ & all \\
\hline $\begin{array}{c}\text { Debris } \\
\text { floods }\end{array}$ & 0.3 to 0.6 & all \\
\cline { 2 - 3 } & $>0.6$ & $\geq 2.7$ \\
\hline $\begin{array}{c}\text { Debris } \\
\text { flows }\end{array}$ & $>0.6$ & $<2.7$ \\
\hline
\end{tabular}

Table 1. Class limits for debris flows, debris floods, and floods as adapted from [43].

We used a similar approach to predict potential geomorphic process types for every channel within the study area (irrespective of whether it contained a fan). However, we refined the approach to leverage the higher spatial data resolution, greater number of channels for statistical analyses, and modern GIS processing capabilities available to our study; and to consider major changes in valley orientation as shown in Figure 7. Specifically, we applied total stream network length, the total channel length upstream of a given stream segment to the stream segment farthest from the fan apex, instead of the watershed length [44].

The major steps of the analysis were:

1. Collect statistics on watershed length and Melton ratios for stream segment(s) intersecting the upstream edge of each fan.

2. Use Analysis of Variance (ANOVA) to determine class boundaries that best predict process types for fans that have been previously studied in detail. Following analyses of these streams, results were compared to process types interpreted for fans during the desktop study.

3. Update class boundaries to predict process types for all stream segments in the study area, regardless of whether they intersected fans.

Class boundaries for channels that do not intersect a mapped fan are presented in Table 2 and are based on 
Melton ratio and total network stream length. Class boundaries for channels with a mapped fan at the outlet are presented in Table 3; these use fan gradient in addition to Melton ratio and stream network length. Process-type predictions are more reliable for channels with a mapped fan.

Hydrogeomorphic process types predicted from watershed morphometry are subject to limitations. In particular, the classification describes the potential process type, but does not consider the geomorphic or hydroclimatic conditions needed to actually generate events. As such, channels may be classified as "debris flow" or "debris flood" without evidence for previous events.

Watershed conditions that affect hydrogeomorphic process types cannot be considered using a purely statistical approach [43]. For example, a fan could be located at the outlet of a gentle valley, but where a debrisflow tributary enters near the fan apex. In this situation, debris flows could run out onto a fan that is otherwise subject to floods or debris floods from the main tributary. Other exceptions include hanging valleys, where the lower channel sharply steepens below a gentle upper basin.

\begin{tabular}{|l|c|c|}
\hline Process & Melton Ratio & Stream Length (km) \\
\hline Floods & $<0.2$ & all \\
\hline $\begin{array}{l}\text { Debris } \\
\text { floods }\end{array}$ & 0.2 to 0.5 & all \\
\cline { 2 - 3 } & $>0.5$ & $>3$ \\
\hline $\begin{array}{l}\text { Debris } \\
\text { flows }\end{array}$ & $>0.5$ & $\leq 0.3$ \\
\hline
\end{tabular}

Table 2. Class boundaries using total stream network length for watersheds without a mapped fan.

\begin{tabular}{|c|c|c|c|}
\hline \multirow{2}{*}{ Process } & $\begin{array}{c}\text { Melton } \\
\text { Ratio }\end{array}$ & $\begin{array}{c}\text { Stream } \\
\text { Length (km) }\end{array}$ & $\begin{array}{c}\text { Fan } \\
\text { Gradient } \\
\text { (degrees) }\end{array}$ \\
\hline Floods & $<0.2$ & all & $<3$ \\
\hline \multirow{2}{*}{$\begin{array}{c}\text { Debris } \\
\text { floods }\end{array}$} & 0.2 to 0.5 & all & $\geq 3$ \\
\cline { 2 - 4 } & $\geq 0.5$ & $\leq 3$ & all \\
\cline { 2 - 4 } & $>0.5$ & $>3$ & all \\
\hline $\begin{array}{c}\text { Debris } \\
\text { flows }\end{array}$ & $>0.5$ & $>5$ \\
\hline
\end{tabular}

Table 3. Class boundaries using total stream network length for watersheds with a mapped fan.

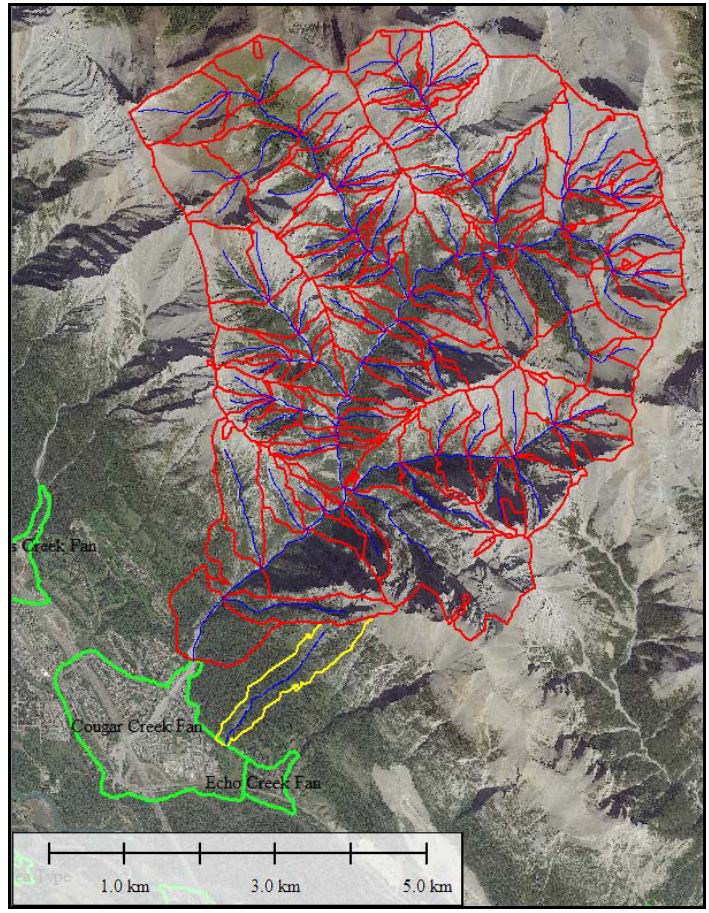

Figure 7. Cougar Creek Debris Fan (green line) and catchments (red line) for individual channel segments within the upstream watershed (blue line), and a second smaller watershed with connectivity to Cougar Creek fan (yellow line).

\subsection{Hazard Frequency}

Table 4 lists the relative hazard frequency ratings and corresponding annual return period ranges assigned to each fan. Note that frequency is the inverse of return period (higher frequency events have a smaller return period).

\begin{tabular}{|c|c|}
\hline Relative Frequency & $\begin{array}{c}\text { Approximate Return Period } \\
\text { Range (years) }\end{array}$ \\
\hline High & $<30$ \\
\hline Moderate & $30-100$ \\
\hline Low & $>100$ \\
\hline
\end{tabular}

Table 4. Relative Frequency and Return Period Categories.

Hazard frequency estimates were based on surface evidence for geomorphic activity within the basin and fan, as shown by the examples in Figure 8 and Figure 9. As such, they apply to events large enough to produce visible surface evidence. Dense tree cover, for example, could obscure small events that would not be detected at the scale of study. Accordingly, the ratings are relative measures. However, hazard and risk is dominated by large events and neglecting smaller ones is thus of lesser consequence. 


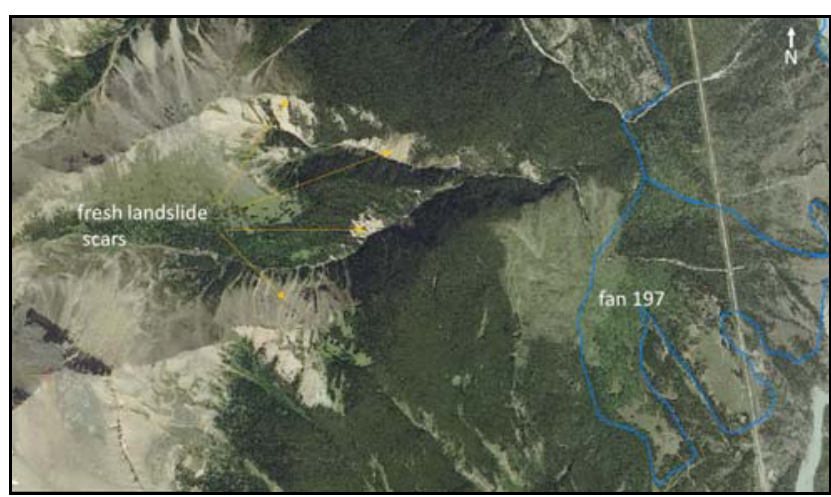

Figure 8. Example of evidence for recent landslide activity within the basin of Fan No. 197.

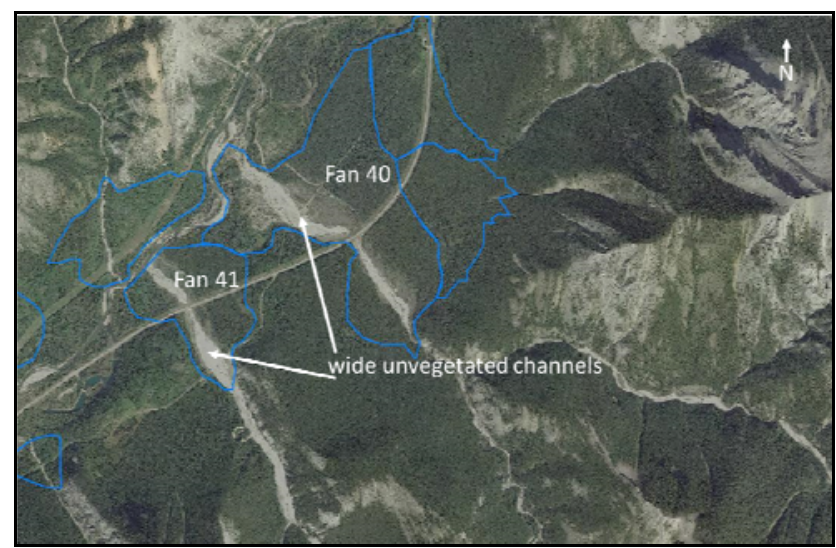

Figure 9. Example of vegetation evidence for recent debris floods on Fan Nos. 40 and 41.

Geomorphic evidence for "activity" within each basin (e.g., erosion, landslides, and sediment transport) was rated as Low, Moderate, or High, based on the freshness of channel deposits and whether basin sediment supply is limited or unlimited. Supply-unlimited basins typically contain erodible deposits and/or landslides that continuously charge the channel with sediment and debris; these will trigger an event every time a hydroclimatic threshold is exceeded. Most debris-flood prone watersheds are supply-unlimited due to the abundance of often deep alluvial beds. Supply-limited basins are typically rocky or heavily vegetated, with fewer sediment and debris sources for the main channel; these require time to accumulate debris before a hydroclimatic event can lead to renewed debris flow activity.

Geomorphic evidence for activity on each fan (e.g., evidence for recent events) is rated as Low, Moderate or High based on freshness and visibility of recent sediment deposits and the estimated age of vegetation: pioneer $(<2$ year), young ( $<50$ year), or mature $(>50$ year). The rating considered evidence for geomorphic activity anywhere on the fan surface.

\subsection{Avulsion Susceptibility}

During an event, flows may avulse entirely out of the existing channel into a different portion of the fan, or part of the flow may avulse while the remainder remains in the existing channel.

We assigned avulsion susceptibility categories as High, Moderate, or Low, based on the level of channel confinement and surface evidence for previous avulsions. Fans with previously recorded avulsions were assigned a High rating.

Channel confinement level was based on estimated bank height and the presence of locations where confinement could be reduced during an event (e.g., channel bends, changes in channel gradient, channel constrictions at road crossings).

Surface evidence for previous avulsions was based on vegetation evidence and the presence of relict channels, lobes, and deposits on the fan surface (e.g., Figure 10). These features can be detected, if present, on LiDAR hillshades; interpretations are less certain for areas without LiDAR coverage.

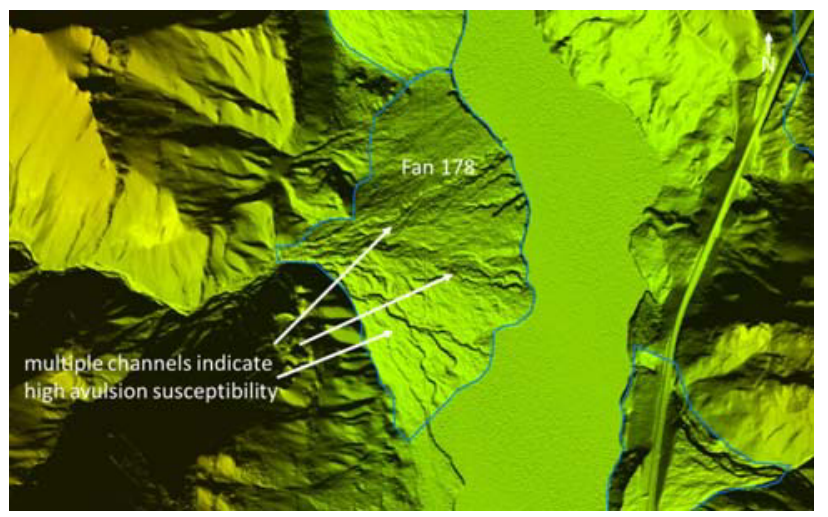

Figure 10. Example of evidence for High avulsion susceptibility on fan no. 178 . 


\subsection{Bank Erosion Susceptibility}

Bank erosion refers to widening of the existing channel during an event. We assigned bank erosion susceptibility categories as High, Moderate, or Low, based on surface signs of previous channel widening (e.g., Figure 11). In general, the higher ratings applied to channels with moderate or lower levels of confinement. Because the remote-sensed imagery represents a snapshot in time, estimating channel widening in relation to some "equilibrium" channel width is difficult. Bank erosion susceptibility is also controlled by factors not possible to determine remotely, such as channel bank vegetation and sediment grain size distribution as well as sediment apparent cohesion. As such, this rating is subject to more uncertainty than other hazard factors.

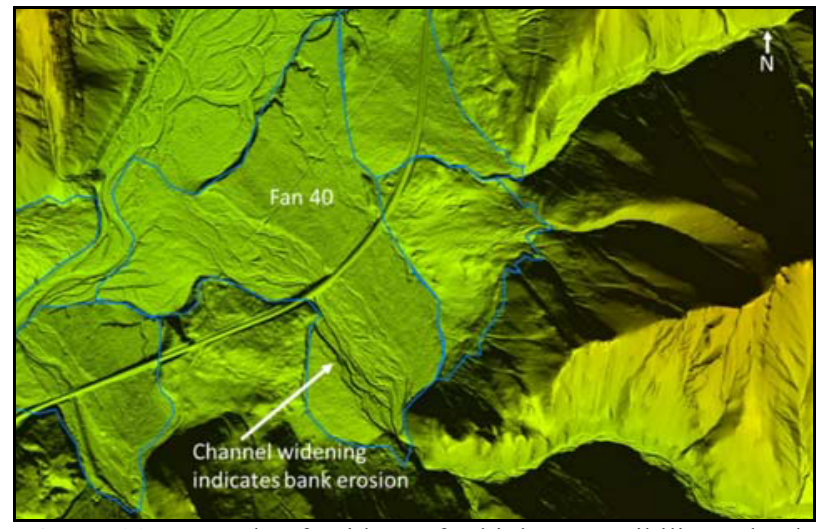

Figure 11. Example of evidence for high susceptibility to bank erosion on Fan no. 40.

\subsection{Landslide Dam Outbreak Flood Potential}

We assigned landslide dam outbreak flood potential ratings as High, Moderate, or Low based on evidence of past landslide dams, presence of large landslide scars with the potential to travel to the valley floor, and presence of channel sections potentially susceptible to blockage (e.g., channel constrictions). Figure 12 shows an example of landslide dam locations in Cougar Creek basin. Note that actual landslide dams are not visible at the resolution of the figure; the interpretation was based on the combination of characteristics noted above and were field checked during 2013.

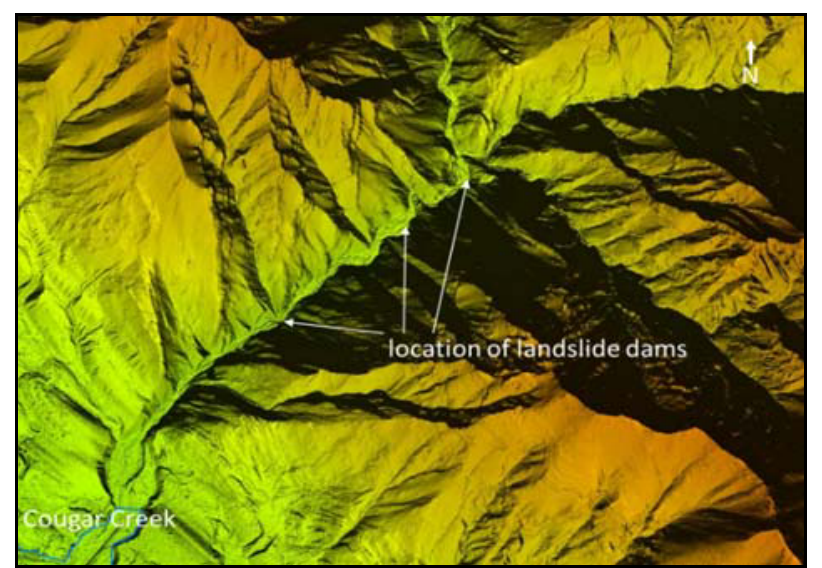

Figure 12. Example of evidence for landslide dam outbreak flood potential in Cougar Creek basin.

\section{Elements at Risk Inventory}

We inventoried development on fans in GIS that could be subject to losses due to a hydrogeomorphic process. Development considered includes roads, highways, pipelines, transmission lines, railways, and buildings. Specific building locations were only known for a small portion of the study area, including the Town of Canmore and Municipal District of Bighorn. For the remainder, the presence of buildings is inferred from municipal tax assessment data linked to cadastral parcels (property boundaries).

We used tax assessment data to characterize ownership, usage, and the assessed value of all properties in the study area (regardless of location). Of the 710 fans mapped within the prioritization study area, 51 intersected parcels with building improvements totalling $\$ 1.5$ billion, or $5 \%$ of the $\$ 33$ billion in building improvements in jurisdictions within the prioritization area. Tax assessments do not consider building contents or full replacement cost, and do not include some large industrial facilities, such as two large concrete and limestone plants on Exshaw and Jura Creek fans in the Municipal District of Bighorn. As such, this figure should be considered a minimum estimate of the value of development on fans within the study area.

\section{Fan Prioritization}

We prioritized hazard sites based on the relative likelihood that an event will occur and have the potential to result in consequences to elements at risk. The primary objective was to rank sites for further site-specific assessment and long term monitoring. Although the approach is risk-based, it is not formally a risk assessment because the priority scores do not provide an absolute probability of some severity of consequence.

Priority scores were calculated as follows:

$$
P_{F}=P_{H} \times \sum S_{t} \times \sum C_{t}
$$

where

$P_{F}$ is the numerical priority score, $P_{H}$ is the weighting for estimated hazard probability

$S_{t}$ are the weightings for proxies for spatial probability of flow impact and

$C_{t}$ are weightings for the presence of each element at risk

The scores were evaluated based on percentile rank within each hazard type. Table 5 shows the percentile ranks used to define Low, Moderate, and High priority categories for each hazard site.

\begin{tabular}{|c|c|}
\hline Priority Category & Percentile Rank \\
\hline High & $\geq 90$ \\
\hline Moderate & $\geq 50$ to $<90$ \\
\hline Low & $<50$ \\
\hline
\end{tabular}

Table 5. Hazard site priority categories.

Table 6 lists components of Equation 1 and the range in possible weightings. Avulsion susceptibility, bank erosion susceptibility, and landslide outbreak flood 
potential parameters are chosen as factors that can be estimated at regional scale and that can result in flows outside the main channel, resulting in road impact. Ratings for these factors represent proxies for the spatial probability that flows will occur outside of the active stream channels, where they could potentially impact existing elements at risk. Loss potential ratings are based on the presence and value of development intersecting the fan inventory that could potentially be subject to losses due to a hydrogeomorphic process.

\begin{tabular}{|c|c|c|}
\hline Component & Parameters & $\begin{array}{c}\text { Range in } \\
\text { Possible } \\
\text { Weightings }\end{array}$ \\
\hline $\begin{array}{l}\text { Hazard } \\
\text { frequency }\end{array}$ & $\begin{array}{l}\text { Hazard } \\
\text { frequency }\end{array}$ & $3-9$ \\
\hline \multirow{3}{*}{$\begin{array}{l}\text { Proxies for } \\
\text { spatial } \\
\text { probability } \\
\text { of flow } \\
\text { impact }\end{array}$} & $\begin{array}{l}\text { Avulsion } \\
\text { susceptibility }\end{array}$ & $1-3$ \\
\hline & $\begin{array}{l}\text { Bank erosion } \\
\text { susceptibility }\end{array}$ & $1-3$ \\
\hline & $\begin{array}{l}\text { Landslide dam } \\
\text { outbreak flood } \\
\text { potential }\end{array}$ & $1-3$ \\
\hline $\begin{array}{l}\text { Loss } \\
\text { potential }\end{array}$ & $\begin{array}{l}\text { Presence of } \\
\text { elements at risk }\end{array}$ & $1-83$ \\
\hline
\end{tabular}

Table 6. Components of the prioritization score.

\section{Results}

The study results are presented on a searchable web application termed the "Alberta Hydro Hazard Info Tool" (AHHIT) (Figure 13). The application allows the user to view all fans, search or navigate to a fan of interest, and display the priority rating and detailed characteristics of the hazard and elements at risk. It also displays a morphometric-based prediction of potential hydrogeomorphic hazard type for all stream channels across the study area.

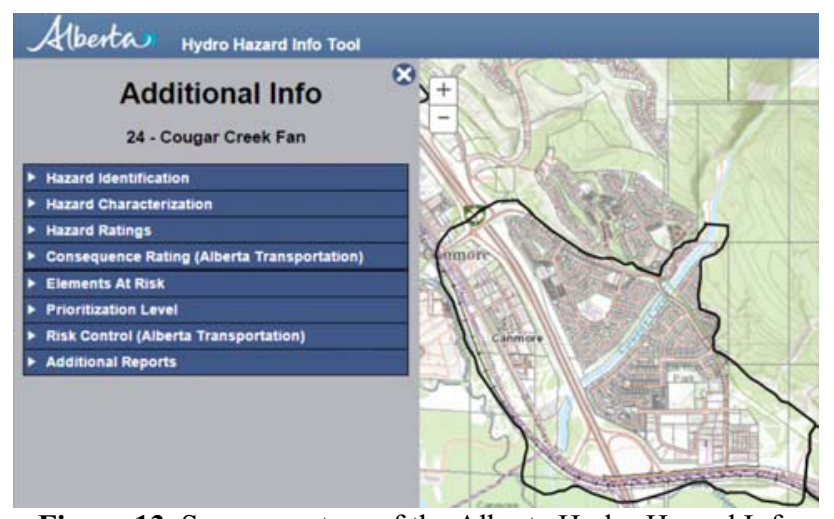

Figure 13. Screen-capture of the Alberta Hydro Hazard Info Tool (AHHIT), centered on Cougar Creek fan in Canmore.
Figure 14 shows the distribution of High, Moderate, and Low priority fans across the study area. A total of 57 fans were rated as High priority, 227 as Moderate priority, and 247 as Low priority. Of these, 67 fans intersected parcels containing buildings development, with the remainder intersecting linear infrastructure (pipelines, railways, or roads). Of those fans without buildings development, 35 fans received High priority ratings due to higher hazard characterization scores or intersection with multiple types of linear infrastructure.

Cougar Creek fan, located in the Town of Canmore, received the highest priority score in the study. This fan contains the highest value of development of any fan in Alberta (over \$1B), and is traversed by a major railway and the Trans-Canada Highway. The design and construction of risk reduction measures including channel erosion protection works and a debris barrier upstream of the fan apex are presently underway. More detailed hazard and risk assessments have also been completed for 15 fans in Canmore and the neighbouring Municipal District of Bighorn. These are the only jurisdictions, to BGC's knowledge, where detailed hydrogeomorphic risk assessments have been completed in Alberta to date.

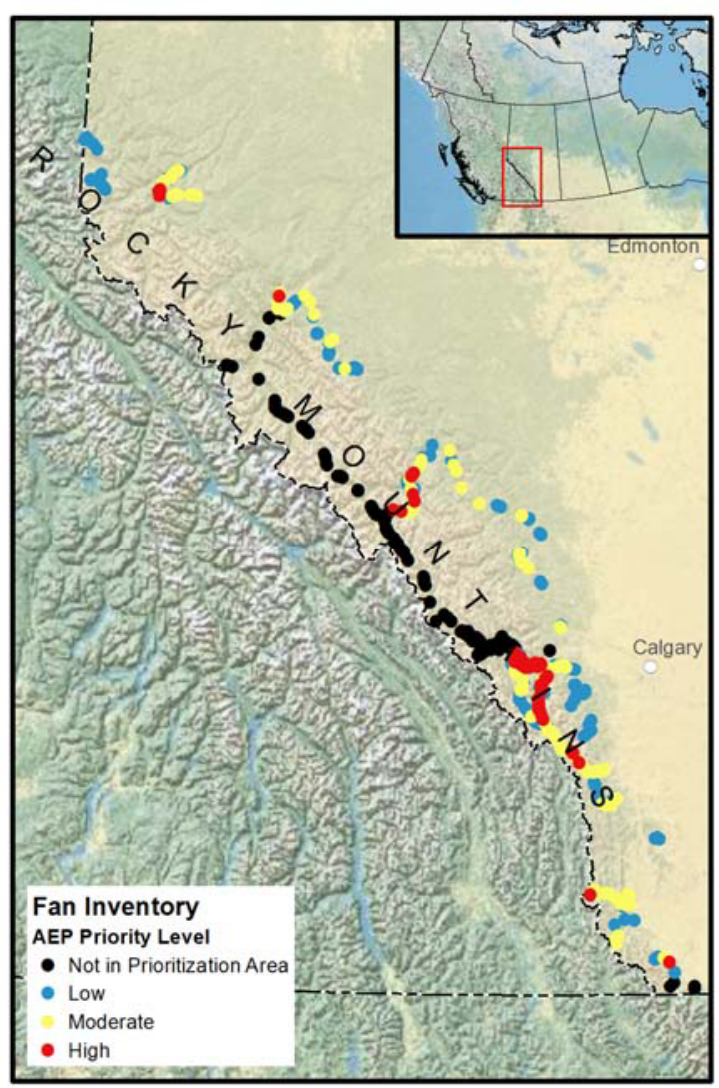

Figure 14. Point locations of steep creek fans. 


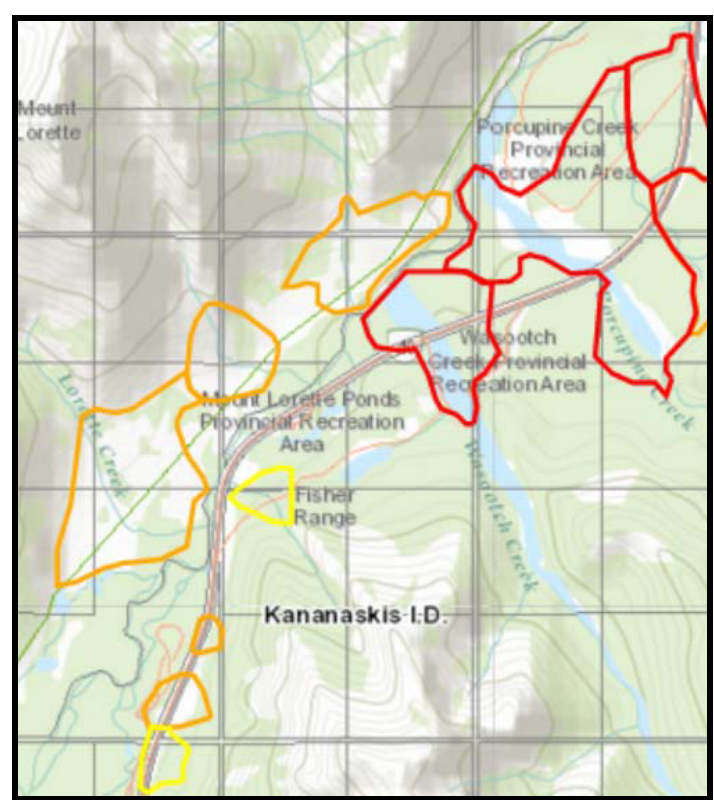

Figure 15. Boundaries of high (red), moderate (orange) and low (yellow) priority fans in Kananaskis, Alberta, as shown on the AHHIT web-application.

\section{Conclusions}

This study provides the Government of Alberta with an inventory and risk-based prioritization of steepcreek fans intersecting municipal development and major roads and highways in Alberta. We characterized 710 fans and prioritized 531 fans under provincial jurisdiction based on hazard levels, proxies for potential impact to elements at risk, and presence and value of elements at risk.

The study results are presented on a geospatial web application that allows the user to review fan hazards, identify development at risk, and prioritize fans for further assessment and risk reduction planning. Future upgrades to the application could include the ability to manage periodic geohazard inspections and reporting, and tools to support emergency planning.

\section{Acknowledgements}

This study was completed under contract to Alberta Transportation and Alberta Environment and Parks.

\section{References}

1. Wood J. (2013). Province boosts cost of Alberta floods to $\$ 6$ billion. Report prepared for Calgary Herald dated September 23, 2013.

2. Church M. (2013). Steep headwater channels. Treatise on Geomorphology, Vol. 9, Academic Press, pp. 528-549.

3. Jordan, P. and Slaymaker O. (1991). Holocene sediment production in Lillooet River basin, British Columbia: A sediment budget approach. Geographie physique et Quaternaire, 45(1), 45-57.

4. Dadson, S.J. and Church M. (2005). Post-glacial topographic evolution of glaciated valleys: a stochastic landscape evolution model. Earth Surface Processes and Landforms, 30(11), 1387-1403.

5. Friele, P.A. and Clague J.J. (2002). Younger Dryas readvance in Squamish river valley, southern Coast Mountains British Columbia. Quaternary Science Reviews, 21(18-19), 1925-1933.

6. BGC Engineering. (BGC). (2014). Hydroclimatic Analysis of the June 2013 Storm. Report prepared for the Town of Canmore dated August 1, 2014.

7. BGC Engineering Inc. (BGC). (2014). Cougar Creek Debris Flood Hazard Assessment. Report prepared for the Town of Canmore dated March 7, 2014.

8. Environment Canada. 2010. Canadian monthly climate data and 1981-2010 normals. Environment Canada, Ottawa, Ontario.

9. BGC Engineering Inc. (BGC). (2013). Cougar Creek 2013 Forensic Analysis and Short-term Debris Flood Mitigation. Report prepared for the Town of Canmore dated December 11, 2013.

10. BGC Engineering Inc. (BGC). (2014). Three Sisters Creek Debris Flood Hazard Assessment. Report prepared for the Town of Canmore dated October 31, 2014.

11. BGC Engineering Inc. (BGC). (2014). Jura Hazard Debris Flood Hazard Assessment. Report prepared for the Municipal District of Bighorn dated March 1, 2015.

12. BGC Engineering Inc. (BGC). (2014). Cougar Creek Debris Flood Risk Assessment. Report prepared for the Town of Canmore dated June 11, 2014.

13. BGC Engineering Inc. (BGC). (2015). Flood Mitigation Prioritization. Report prepared for Alberta Transportation, January 20, 2016

14. BGC Engineering Inc. (BGC). (2015). Steve's Creek Debris-Flow Hazard Assessment. Report prepared for the Municipal District of Bighorn dated November 23, 2015.

15. BGC Engineering Inc. (BGC). (2015). Harvie Heights Creek Debris-Flood and Debris-Flow Hazard Assessment. Report prepared for the Town of Canmore dated June 5, 2015.

16. BGC Engineering Inc. (BGC). (2015). Harvie Heights Creek Debris-Flood Risk Assessment. Report prepared for the Town of Canmore dated May 27, 2015.

17. BGC Engineering Inc. (BGC). (2015). Harvie Heights Creek Preliminary Debris-Flood and DebrisFlow Mitigation Design. Report prepared for the Town of Canmore dated May 25, 2015.

18. BGC Engineering Inc. (BGC). (2015). Grotto Creek Debris-Flood Hazard Assessment. Report prepared for the Municipal District of Bighorn dated May 22, 2015.

19. BGC Engineering Inc. (BGC). (2015). Heart Creek Debris-Flood Hazard Assessment. Report prepared for the Town of Canmore dated April 30, 2015.

20. BGC Engineering Inc. (BGC). (2015). Heart Creek Debris-Flood Risk Assessment. Report prepared for the Town of Canmore dated April 27, 2015.

21. BGC Engineering Inc. (BGC). (2015). Heart Creek Preliminary Debris-Flood Mitigation Design. Report 
prepared for the Town of Canmore dated April 24, 2015.

22. BGC Engineering Inc. (BGC). (2015). Stoneworks Creek Debris-Flow Hazard Assessment. Report prepared for the Town of Canmore dated April 10, 2015.

23. BGC Engineering Inc. (BGC). (2015). Exshaw Creek and Jura Creek Debris Flood Risk Assessment. Report prepared for the Municipal District of Bighorn dated March 1, 2015.

24. BGC Engineering Inc. (BGC). (2015). Exshaw Hazard Debris Flood Hazard Assessment. Report prepared for the Municipal District of Bighorn dated March 1, 2015.

25. BGC Engineering Inc. (BGC). (2015). Exshaw Creek and Jura Creek Preliminary Debris-Flood Mitigation Design. Report prepared for the Municipal District of Bighorn dated March 1, 2015.

26. BGC Engineering Inc. (BGC). (2015). Cougar Creek Debris Floods: Risk Reduction Optimization. Report prepared for the Town of Canmore dated February 2, 2015.

27. BGC Engineering Inc. (BGC). (2015). Three Sisters Creek Debris Flood Risk Assessment. Report prepared for the Town of Canmore dated January 20, 2015.

28. BGC Engineering Inc. (BGC). (2015). Stone Creek Debris-Flow Hazard Assessment. Report prepared for the Town of Canmore dated January 16, 2015.

29. BGC Engineering Inc. (BGC). (2015). Stone Creek Debris-Flow Risk Assessment. Report prepared for the Town of Canmore dated January 13, 2015.

30. Jackson, Jr., L.E. (1987). Debris flow hazard in the Canadian Rocky Mountains. Geological Survey of Canada Paper, 86-11.

31. de Scally, F.A. 1999. Alteration and Restoration of Alluvial Fan Processes in the Lower Bow Valley, Banff National Park. Report prepared for Parks Canada: Ecosystem Section, Heritage Resources Conservation, Banff National Park. Kelowna, B.C.

32. AMEC Earth and Environmental (AMEC). (2006). Geohazards Review Highway 40 / Highway 541 corridor, Southwestern Alberta. Report prepared for Alberta Transportation.

33. AMEC Earth and Environmental (AMEC). (2013). Highway and Geohazard Assessments of June 2013 Flood Damage - Highways 940 (Forestry Trunk Road) and 532 (Kananaskis Country) Consulting Services Contract CON0014932. Revision 1 Updated to Non-DRP Site Cost Estimates and Assessments. Report prepared for Alberta Transportation.

34. Alberta Environment and Parks (AEP). (2015). Geo Alberta 1:20k Stream Dataset. Provided by AEP, May 16, 2014.

35. Jakob M. and Jordan J. (2001). Design flood estimates in mountain streams - the need for a geomorphic approach. Canadian Journal of Civil Engineering, 28, 425-439.

36. Jakob M. Clague J.J. and Church M. (2015). Rare and dangerous: Recognizing extraordinary events on streams. Canadian Water Resources Journal, DOI: 10.1080/07011784.2015.1028451

37. AMEC Earth \& Environmental Ltd. (2007). Sediment Transport and Flood Hydrology in Cougar Creek. Report prepared for Town of Canmore.

38. Water Survey of Canada (WSC). (2010). Hydrometric Data. Available from: http://www.wsc.ec.gc.ca/applications/H2O/indexeng.cfm [accessed July 4, 2014].

39. Jackson Jr. L.E. Kostaschuk, R.A. and MacDonald, G.M. (1987). Identification of debris flow hazard on alluvial fans in the Canadian Rocky Mountains. Geological Society of America Reviews in Engineering Geology, 7, 115-124.

40. Strahler A. (1952). Hypsometric (area-altitude) analysis of erosional topology. Geological Society of America Bulletin, 63(11), 1117-1142.

41. Melton M.A. 1957. An analysis of the relation among elements of climate, surface properties and geomorphology. Office of Nav Res Dept Geol Columbia Univ, NY. Tech Rep 11.

42. Wilford D.J. Sakals M.E. Innes J.L. Sidle R.C. and Bergerud W.A. (2004). Recognition of debris flow, debris flood and flood hazard through watershed morphometrics. Landslides, 1, 61-66.

43. Wilford, D. (2014). Pers. Comm., May 28, 2014. 